MATEC Web of Conferences 9, 02004 (2013)

DOI: $10.1051 /$ matecconf/20130902004

(C) Owned by the authors, published by EDP Sciences, 2013

\title{
Experimental study of the fire performance of wooden facades
}

\author{
Martin Teibinger, Irmgard Matzinger and Peter Schober
}

\author{
Holzforschung Austria, Vienna, Austria
}

\begin{abstract}
The paper presents an overview of test results of 21 full-scale tests of wooden facades which were performed during an Austrian research project [1]. These tests were carried out according to ÖNORM B 3800-5 [2] and were the basis of Austrian classifications without further testing of the fire performance of wooden facades [3].
\end{abstract}

\section{FIRE SCENARIO}

The spread of a fire on a facade is influenced by both the location of the initial fire and its intensity. Actual fires as well as several fire tests have shown that a fire inside a building with a flashover has the most detrimental effect on the facade. The Flames reach lengths up to $5 \mathrm{~m}$. The length of the flames depends on the fire load, the size and the geometry of the windows. They generally reach heights of two floors above the fire source, given a conventional height of the floors.

The general safety goals are to ensure the load bearing capacity of the building over a defined duration, to avoid spread of fire to other buildings or fire compartments, to ensure the escape or the rescue of inhabitants and the safety of the rescue team. Based on these general safety goals the Austrian building authority demands no fire spread over more than one storey above the fire source over a period of 30 minutes [5]. Additional requirements include the temperature in the ventilation voids and the prevention of the collapse of larger parts.

In former times the influence of wooden facades to the fire spread had been discussed. Some experts were afraid of the combustibility of these facades and of their influence to the fire. Kotthoff [4] carried out some natural fire tests of wooden facades and wooden balconies on a four storey high building in Merkers. These tests were part of an international project with Swiss, Finnish and Austrian participation. The tests have proved that there is no significant influence of the combustibility of the wooden facade, if the ventilation voids were sealed with fire barriers. After the burnout of the fire load in the initial floor the fire at the facade decreased and after 60 minutes the fire stopped without extinguishing. Based on these tests and some additional full-scale tests guidelines with technical solutions of the fire barriers in the ventilation cavities for Switzerland [6] and Germany [7] have been published. While there may not be a fire spread over more than one storey above the fire source over a period of 30 minutes in Austria, in Germany this limit is one storey higher and the period is only 20 minutes. Due to these different safety goals additional tests with stricter solutions were needed. However, Kotthoffs test results were very important for the discussions with representatives of building regulations and fire brigades.

In Austria the use of fire barriers for ventilated facades and also for ETIĆs is required for buildings with more than 3 storeys. The results of the research project and the developed constructive solutions were essential for buildings with more than 3 storeys.

\section{TEST METHODES}

The Austrian tests were performed according to ÖNORM B 3800-5 [2]. Differing to the ISO and the UK test method the Austrian and the German methods do not simulate the entire length of the flames

This is an Open Access article distributed under the terms of the Creative Commons Attribution License 2.0, which permits unrestricted use, distribution, and reproduction in any medium, provided the original work is properly cited. 
MATEC Web of Conferences

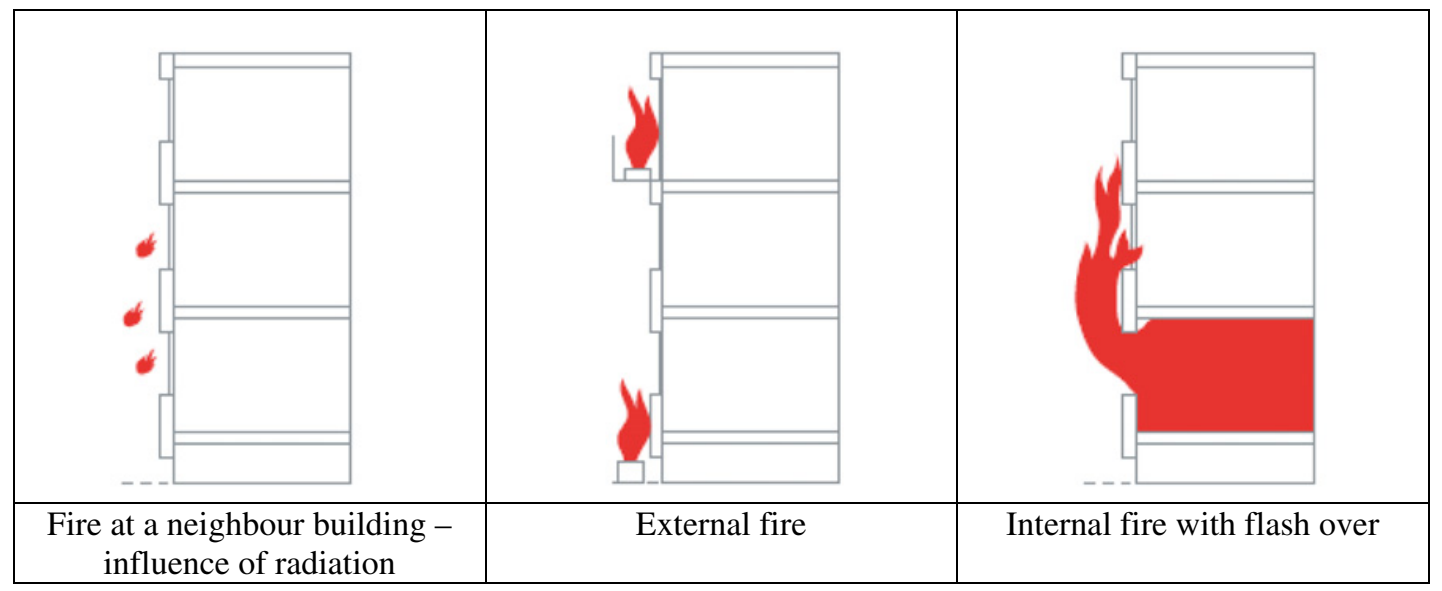

Figure 1. Fire scenarios on the façade [4].

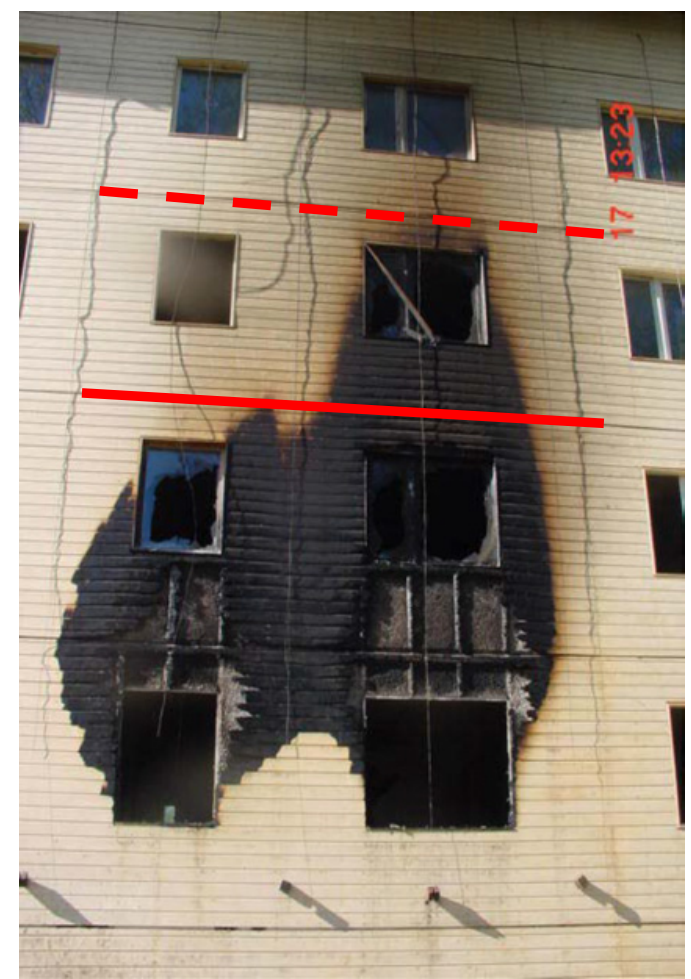

Figure 2. Damages of the wooden façade after the natural fire tests in Merkers [4] and difference of safety goals between Austria and Germany (dashed line).

out of a window after a flash over. The fire load of a $25 \mathrm{~kg}$ wooden crib simulates the peak of the flames, which covers the second floor above the fire source. Kotthoff has analysed the differences between the standards. He has found that there is no significant difference between a natural fire test and a laboratory test with a wooden crib of $50 \mathrm{~kg}$ for the initial fire and also a laboratory test with a wooden crib of $25 \mathrm{~kg}$ for the peak of the flames [8]. 
$1^{\text {st }}$ International Seminar for Fire Safety of Facades, Paris (France), 2013

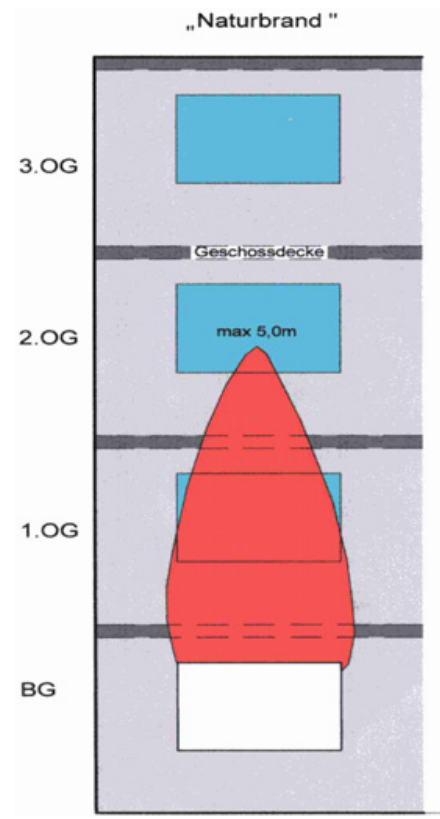

\section{Prüfansatz nach \\ ISO bzw. BS \\ , 3-etagig}

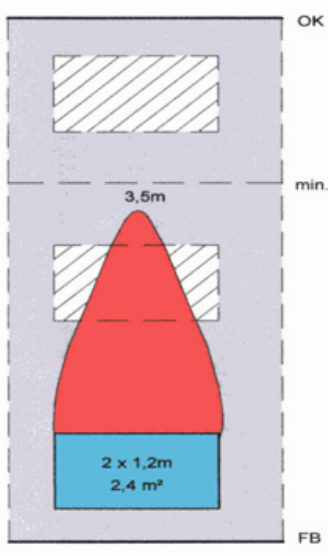

Prüfansatz nach

"2-etagig "

Figure 3. Different test methods: natural fire (left hand side), ISO and BS (in the middle), German and Austrian standards (right hand side).
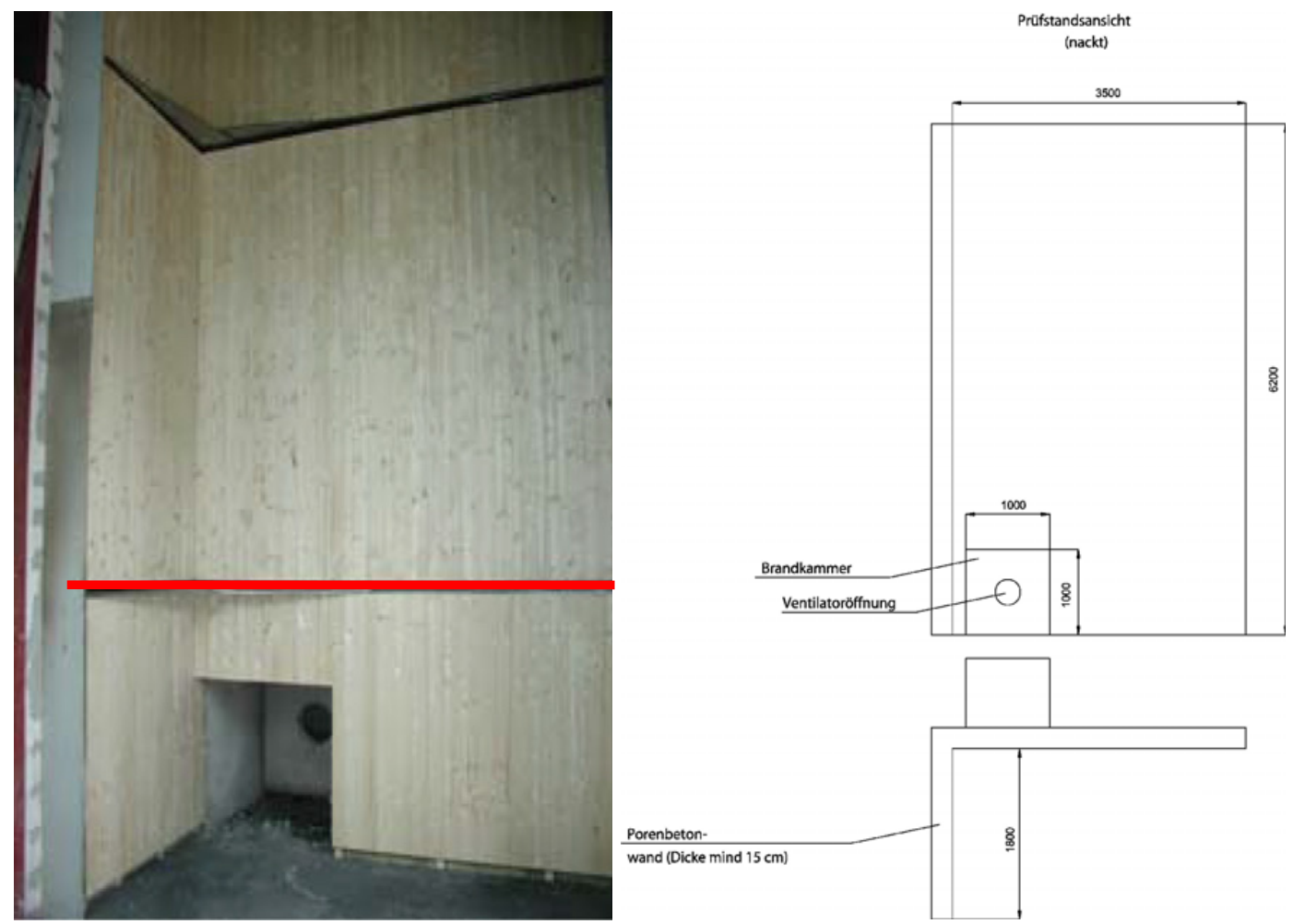

Figure 4. Austrian test method: corner test with a $25 \mathrm{~kg}$ wooden crib. 
MATEC Web of Conferences
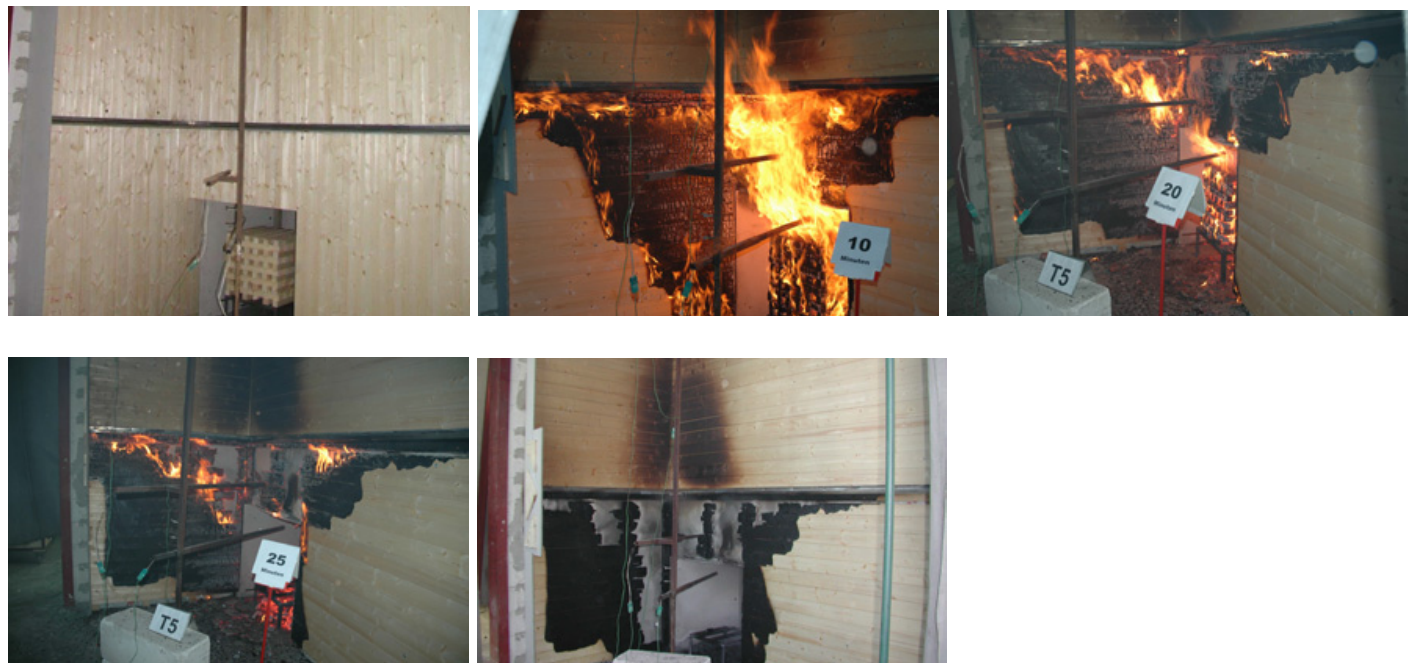

Figure 5. Test process according to ÖNORM B 3800-5 [2].

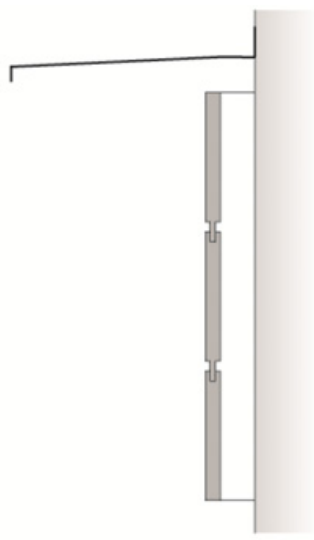

1)

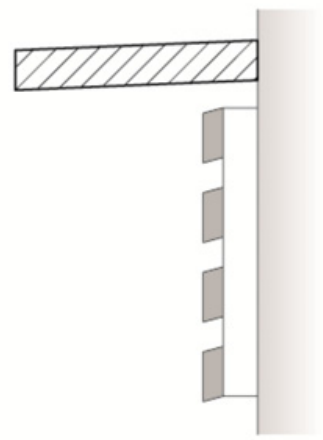

3)
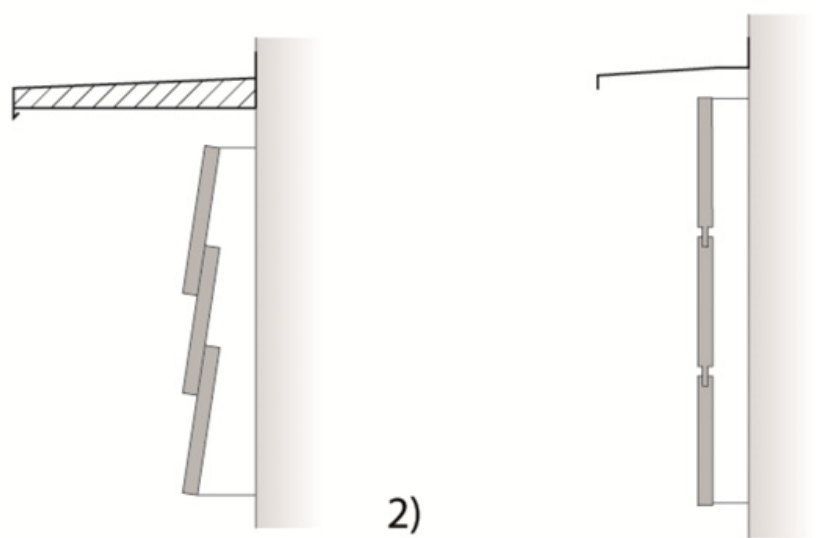

4)

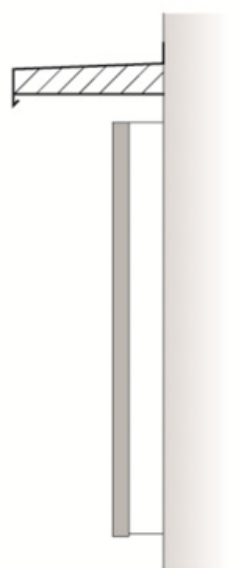

5)

Figure 6. Implementation of the fire barriers (numbers of Table 1) [9]. 
Table 1. Summary of the varied parameters.

\begin{tabular}{|c|c|c|c|c|}
\hline Facade systems & Wood species & Ventilation & Fire barrier & bearing out \\
\hline $\begin{array}{l}\text { Tongue and } \\
\text { groove } 19 \mathrm{~mm} \\
\text { horizontal and } \\
\text { vertical }\end{array}$ & $\begin{array}{l}\text { Spruce with and } \\
\text { without surface } \\
\text { coating }\end{array}$ & Ventilated $30 \mathrm{~mm}$ & $\begin{array}{l}\text { Metal sheets } \\
1 \mathrm{~mm} \text { thick }\end{array}$ & $\begin{array}{l}\text { from } 10 \mathrm{~mm}- \\
170 \mathrm{~mm}\end{array}$ \\
\hline $\begin{array}{l}\text { Multilayered } \\
\text { wooden boards }\end{array}$ & $\begin{array}{l}\text { Larch with and } \\
\text { without surface } \\
\text { coating }\end{array}$ & $\begin{array}{l}\text { Ventilated } 95 \mathrm{~mm} \\
\text { and } 30 \mathrm{~mm} \\
\text { counter battening }\end{array}$ & $\begin{array}{l}\text { Multilayered } \\
\text { boards } 27 \mathrm{~mm}\end{array}$ & $\begin{array}{l}\text { Corner } 100- \\
300 \mathrm{~mm}\end{array}$ \\
\hline \multirow[t]{2}{*}{ OSB $18 \mathrm{~mm}$} & & $\begin{array}{l}\text { Ventilated } 95 \mathrm{~mm} \\
\text { with stone wool } \\
\text { insulation }\end{array}$ & $\begin{array}{l}\text { Multilayered } \\
\text { boards and metal } \\
\text { sheets } 1 \mathrm{~mm} \text { thick }\end{array}$ & \\
\hline & & $\begin{array}{l}\text { Ventilation void } \\
\text { closed with } \\
\text { horizontal } \\
\text { wooden boards }\end{array}$ & & \\
\hline
\end{tabular}

Table 2. Implementation of the fire barriers [9].

\begin{tabular}{|c|c|c|c|}
\hline number & method & material & comments \\
\hline 1 & bearing out $\geq 200 \mathrm{~mm}$ & non-combustible & \multirow{3}{*}{$\begin{array}{l}\text { all horizontal and vertical wooden } \\
\text { facades if the boards } \geq 20 / 70 \mathrm{~mm} \\
\text { and the gaps } \leq 10 \mathrm{~mm}\end{array}$} \\
\hline 2 & bearing out $\geq 200 \mathrm{~mm}$ & $\begin{array}{l}\text { Wooden boards } \\
\text { covered with non- } \\
\text { combustible sheets }\end{array}$ & \\
\hline 3 & bearing out $\geq 200 \mathrm{~mm}$ & $\begin{array}{l}\text { wooden boards } \\
\geq 40 \mathrm{~mm}\end{array}$ & \\
\hline 4 & bearing out $\geq 100 \mathrm{~mm}$ & non-combustible & \multirow{2}{*}{$\begin{array}{l}\text { wooden facades (boards and panels) } \\
\text { without joints }\end{array}$} \\
\hline 5 & bearing out $\geq 100 \mathrm{~mm}$ & $\begin{array}{l}\text { wooden boards } \\
\text { covered with non- } \\
\text { combustible sheets }\end{array}$ & \\
\hline
\end{tabular}

Due to the fact that the length of the flames is about $40 \%$ higher in a corner the Austrian method demands a corner test. The duration of the tests are 30 minutes whereat the wooden crib collapses after between 22 and 25 minutes.

The requirements of the Austrian test standard are:

- No fire spread over the fire barrier (red line in Fig. 4)

- The temperature in the ventilation voids has to be lower than the temperature in front of the facade.

- no collapse of larger parts.

\section{MATERIALS}

Within the 21 fire tests according to the Austrian standard [2] of the research project [1] the fire spread as a function of the wooden cladding in combination with standard coatings, the geometry of the ventilation voids and the dimension and materials of the fire barriers were tested and analysed. 


\section{MATEC Web of Conferences}

\section{RESULTS}

\section{Fire barriers}

Facades with wooden or wood-based claddings can fulfil the safety goals and the requirements of [2], if horizontal fire barriers were used within the range of the floors. These fire barriers have two functions: Firstly they close the ventilation cavities and avoid a fire spread through the cavity because of a "chimney effect". Secondly they keep the flames and their temperature away from the wooden facade above the barrier and avoid its ignition. Metal sheets with a thickness of $1 \mathrm{~mm}$ or even multi-layered wooden boards with a thickness of $27 \mathrm{~mm}$ can be used as fire barriers. In general the barriers need a bearing out of at least $100 \mathrm{~mm}$ and at least $200 \mathrm{~mm}$ in the corner.

In case of any inside corners at the facade additional constructive methods are essential to provide fulfilment of the safety goals, because of the higher lengths of the flames. Based on the tests the following solutions conform to the safety goals and fulfil the requirements of the Austrian standard.

- Type 1:

All wooden facades with or without any windows in the range of the inside corner fulfil the requirements, if there are fire barriers ( $1 \mathrm{~mm}$ thick metal sheets) with a bearing out of $200 \mathrm{~mm}$.
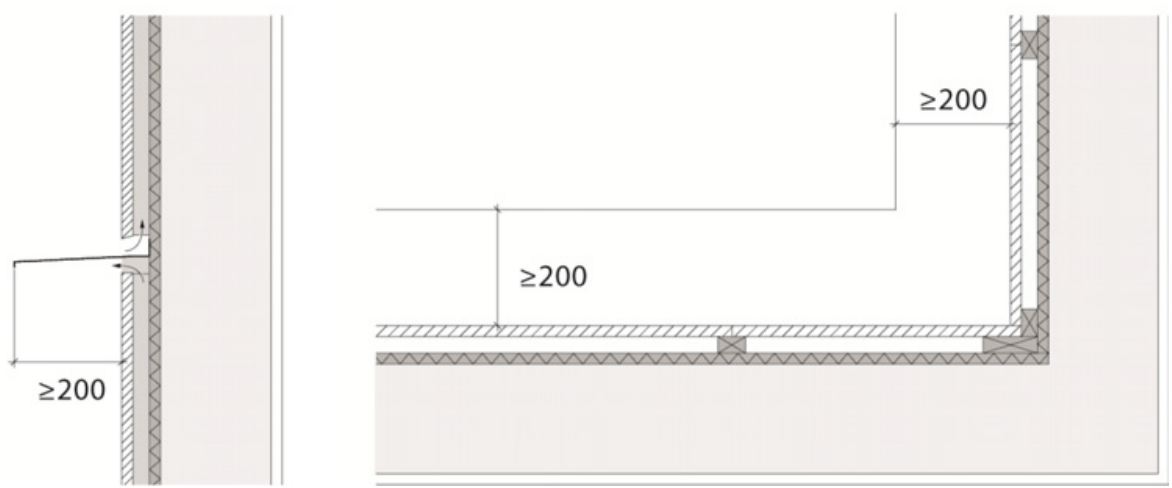

Figure 7. Type 1.

- Type 2:

If windows have a distance of at least $1 \mathrm{~m}$ to the corner and the wooden facade has no joints a bearing out of the fire barrier of $\geq 100 \mathrm{~mm}$ fulfils the requirements.

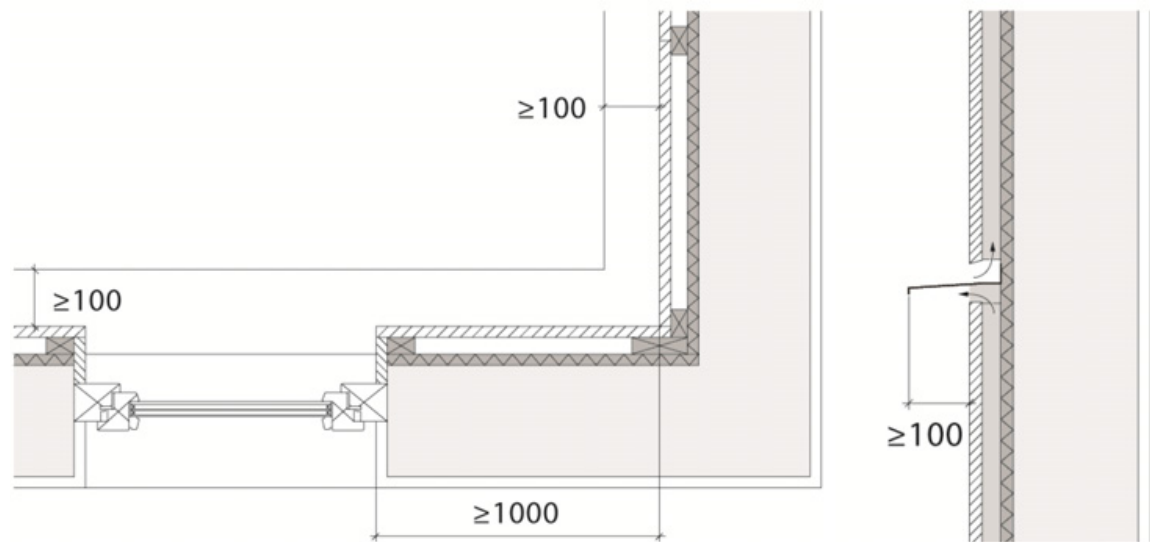

Figure 8. Type 2. 
- Type 3:

If the windows have a distance less than $1 \mathrm{~m}$ to the corner, a higher bearing out of the fire barrier in the corner is needed. There are two different constructive solutions, see Figure 9.
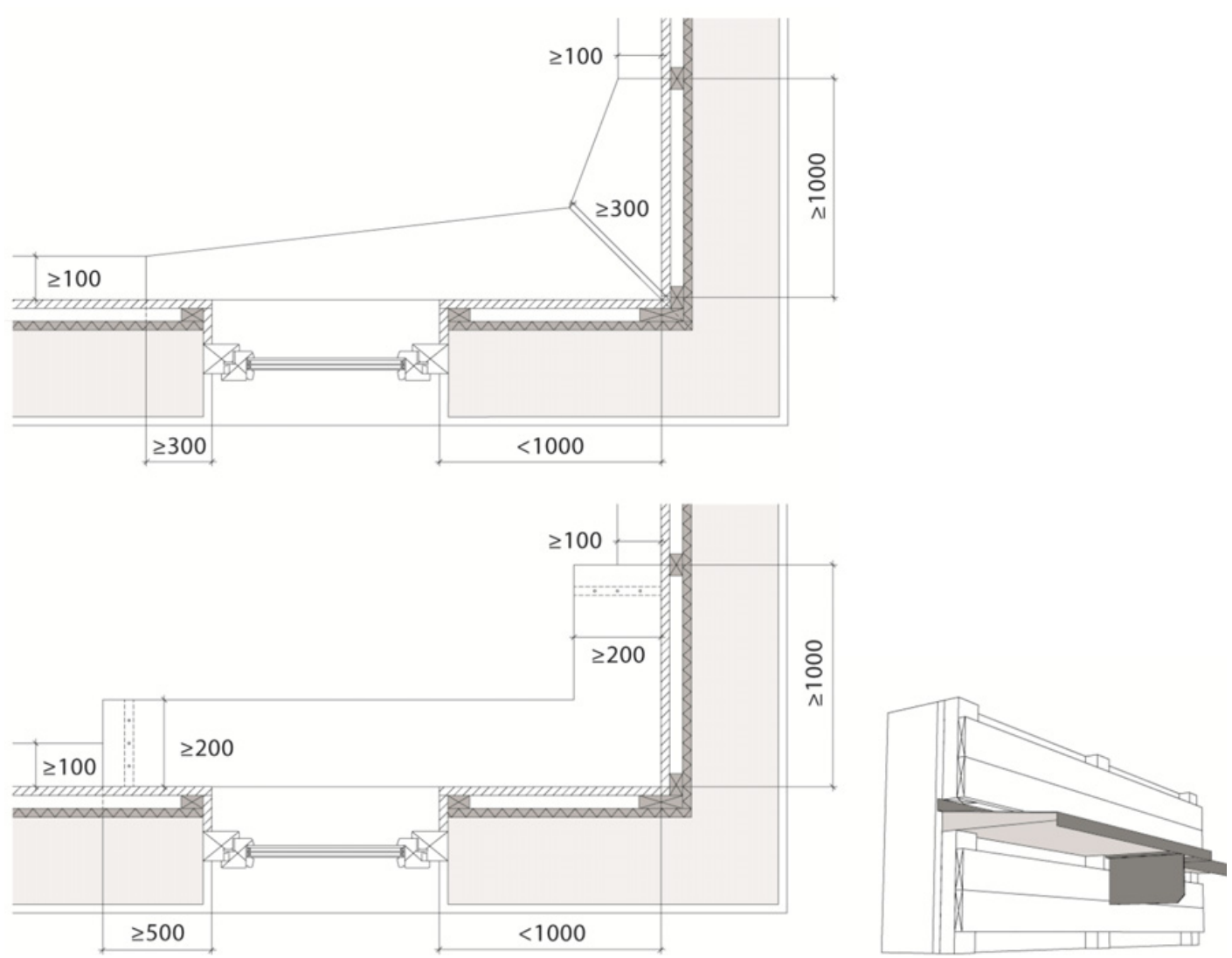

Figure 9. Type 3.

In all cases the fire barriers have to be fixed on the structural wall to close the ventilation voids. If the wall is made of timber, e.g. timber frame or solid timber elements the boards behind the ventilation void have to be made of non-combustible materials. However, wind barriers have no significant influence.

No extensive drop-off of burning parts has been observed. In addition, standard coatings of the wooden facades have no significant effect on the flammability of the wooden facades.

The research project could prove that wooden facades fulfill the requirements when planned and designed correctly. The construction has a higher influence than the combustibility of facades.

\section{References}

[1] Schober, P. et al: Leistungsfähige Holzfassadensysteme. Endbericht, 1. Forschungsjahr, Holzforschung Austria. Wien, 2005.

[2] ÖNORM B 3800-5: Brandverhalten von Baustoffen und Bauteilen Teil 5: Brandverhalten von Fassaden Anforderungen, Prüfungen und Beurteilungen.

[3] ÖNORM B 2332: Brandschutztechnische Ausführung von Fassaden aus Holz und Holzwerkstoffen mit Ausführungsbeispielen. 


\section{MATEC Web of Conferences}

[4] Kotthoff, I.; Bart, B.; Wiederkehr, R.: Holzanwendung im Fassadenbereich. Naturbrandversuche in Merkers (D) vom 15. bis 18. Oktober Grossbrandversuche V1 bis V12 an der MFPA Leipzig. Kurzdokumentation. Unter Mitarbeit von R. Wiederkehr, B. Bart, I. Kotthoff, D. Kehl, H. Kolb, J. Hamm et al. Hg. v. Holzwirtschaft Schweiz Lignum, Holz Bois und MFPA, Leipzig, 2003.

[5] Östman, B.; et al: Fire safety in timber buildings. Technical guideline for Europe. SP Trätek. Stockholm, 2010.

[6] Makiol; Wiederkehr, R.: Fassaden in Holz - Brandschutztechnische Konstruktion. Auszug Rohentwurf 15. August 2005. Hg. v. Lignum. Lignatec.

[7] Winter, W.; Merk, M.: Teilprojekt 02: Brandsicherheit mehrgeschossiger Holzbau. TU München. München. Online: http://www.hb.bv.tum.de/HDZ/forschungsberichte/teilprojekt-2.pdf

[8] Kotthoff, I.: Originalmaßstäbliche Brandprüfverfahren für Fassaden, Leipzig.

[9] Schober, P. S.; Matzinger, I.: Brandschutztechnische Ausführung von Holzfassaden. Zusammenfassung und Erkenntnisse für Gebäudeklasse 4 und 5. Hg. v. Pro Holz Austria (Arbeitsheft 8), Vienna, 2006. 